\title{
Microsatellite based genetic variation among the buffalo breed populations in Pakistan
}

\author{
Tanveer Hussain ${ }^{1}$, Masroor Ellahi Babar ${ }^{1}$, Akhtar Ali $^{1}$, Asif Nadeem ${ }^{2}$, \\ Zia Ur Rehman ${ }^{3}$, Muneeb M. Musthafa ${ }^{4}$, Faiz MMT Marikar ${ }^{5}$ \\ ${ }^{1}$ Department of Molecular Biology, Virtual University of Pakistan, Lahore, Pakistan \\ ${ }^{2}$ Institute of Biochemistry and Biotechnology, ${ }^{3}$ Department of Physiology, \\ University of Veterinary and Animal Sciences, Lahore, Pakistan \\ ${ }^{4}$ Institute of Biological Science, University of Malaya, Kuala Lumpur, Malaysia \\ ${ }^{5}$ General Sir John Kotelawala Defense University, Sri Lanka \\ tanveer.husssain@vu.edu.pk
}

Received: July 11, 2017

Accepted: November 13, 2017

\begin{abstract}
Introduction: Eight microsatellite loci were used to define genetic diversity among five native water buffalo breeds in Pakistan. Material and Methods: Blood samples $(10 \mathrm{~mL})$ from 25 buffaloes of each of the Nili, Ravi, Nili-Ravi, Kundhi, and Azi-Kheli breeds were collected aseptically from the jugular vein into $50 \mathrm{ml}$ Falcon tubes containing $200 \mu 1$ of $0.5 \mathrm{M}$ EDTA. The phenol-chloroform method was used to extract DNA and the regions were amplified for microsatellite analysis. The eight microsatellite markers ETH10, INRA005, ILSTS029, ILSTS033, ILSTS049, ILSTS052, ETH225, and CSSM66 were analysed. Results: The effective number of alleles across all loci was as usual lower than the observed values with a mean value of 2.52 alleles per locus. The overall allele frequency varied from 0.0041 for alleles B, I, and J over respective loci ILSTS052, INRA005, and ILSTS029 to 0.80 for allele H over locus ILSTS029. The average observed and expected heterozygosity values across all polymorphic loci in all studied buffalo breeds were 0.43 and 0.53 , respectively. The overall value for polymorphic information content of considered microsatellite markers was 0.53 , suggesting their appropriateness for genetic diversity analysis in buffalo. The mean Fis value was 0.13 and all loci except ILSTS049 were found significantly deviated from HWE, most likely due to nonrandom breeding. The five buffalo populations were genetically less diverse as indicated by a small mean Fst value (0.07). The average gene flow $(\mathrm{Nm})$ indicative for population migration was calculated as 3.31. Nei's original measures of genetic distance (Ds) revealed ancient divergence of the Nili and Azi-Kheli breeds (Ds $=0.1747)$ and recent divergence of the Nili and Ravi breeds (Ds $=0.0374)$. Conclusion: These estimates of genetic diversity were seen to coincide with phenotypic differentiation among the studied buffalo breeds. The present study reports the first microsatellite marker-based genetic diversity analysis in Pakistani buffalo breeds, and might facilitate similar studies in other livestock breeds of Pakistan.
\end{abstract}

Keywords: buffaloes, breeds, genetic diversity, microsatellite markers, Pakistan.

\section{Introduction}

Water buffaloes have prime importance in the lives of farmers and thus in the economies of many countries worldwide. They are not only draught animals, but also a source of meat, horns, skin, and particularly milk, which may be converted into cream, butter, yoghurt, and many different kinds of cheese (22). The number of water buffaloes in the world has increased rapidly over the past few decades and according to FAO statistics (11), there are about 195 million buffaloes in the world. The current world scenario has glimpsed an amplified loss in wildlife diversity due to ever increasing human intrusion into ecological habitats. Although the trends of loss in livestock diversity are comparatively different, many breeds are near to losing their genetic identity due to the forced gene flow of superior traits from economically healthier populations. The commercially underestimated livestock breeds could provide great economic stimulus in the future in terms of the beneficial allele spectra they have gained as a result of 
adaptation to their environments. Therefore, the FAO Domestic Animal Diversity Information System (DADIS) and Domestic Animal Genetic Resources Information System (DAGRIS) have begun a worldwide campaign for the conservation of within- and betweenbreed genetic diversity in livestock for their sustainable future use befitting their economic and social value. The within- and between-breed genetic variability in livestock predicted by phenotypic attributes can nowadays be validated by the use of molecular markers and their analysis with sophisticated statistical techniques (34). Due to their increasing availability, high polymorphism levels, genome abundance, and dominant nature, molecular markers like DNA microsatellite sequences have replaced the use of allozymes for diversity analyses by reason of the latter's lower loci number and polymorphism levels. In brief, a huge amount of literature can now be reviewed with reference to the use of microsatellite markers in the diversity assessment of various livestock species ( 7 , $8,14,18,30,33)$.

The management of livestock genetics is a rarely adopted course of action in developing countries where people still select future livestock generations based on the productive performance of females. A similar sexbiased trend has also occurred during the domestication process, as evidenced by the presence of more extensive matrilineal than patrilineal genetic diversity in domesticated species (20). These trends have ultimately added and are still adding to the decline in livestock diversity. Agricultural mechanisation and industrial development are other major factors leading to the loss of livestock diversity. This scenario prompts strategic implementation at governmental level of some rules for the sustainability and broadening of domestic animal diversity. There is huge variation in the livestock profiles of developing and developed countries, which is largely based on variation in environment, social preference, economic status, and agricultural extension systems. Therefore, developing nations need to maintain their livestock resources to meet the future challenges of environmental deterioration, rapidly changing consumer inclination towards local dairy products, and breed ownership disputes. These future challenges can only be met if developing nations prioritise the characterisation of their livestock at genetic level.

Of the 195 million buffaloes around the globe about $97 \%$ are of water type. The water buffalo is categorised into two types: the riverine type $(2 n=50)$, mainly distributed in South Asia (about $70 \%$ of the total world population), especially in India and Pakistan, and the swamp type $(2 n=48)$, mainly found in Southeast Asia and Southern China. The domestic river buffalo makes an immense contribution to the Asian agricultural economy, and a larger number of human beings in the world are dependent on this species than on any other livestock group (11). Furthermore, buffalo have advantages over cattle in giving richer milk (5\%-7\% more solid contents) and leaner meat (has lower saturated fat), performing more efficient conversion of low quality feed like rice straw, and providing superior draught strength in waterlogged conditions. Despite having great economic and social importance in the Asian world, the domestic water buffalo is not given great attention in terms of genetic improvement and conservation. So many nondescript buffalo stocks along with breeds of lower economic potential will soon lose their individuality due to either replacement by or huge genetic influx from superior breeds. This situation can be foreseen in India and Pakistan where nondescript and low-potential-type buffaloes are under extreme threat from the substitution and influx of superior genetic traits $(15,16)$.

Pakistan has the second largest buffalo population in the world, at 29 million. The Pakistani buffalo is specifically of the riverine type and provides 30-35 million poor rural farmers and landless labourers with a source of bio fertiliser, fuel, draught power, and ultimately employment, and the general population with milk, meat, and hides (13). The buffalo, being the main dairy animal in Pakistan, constitutes $65 \%$ of the total milk produced in the country, with a share of $32 \%$ in red meat production and $2 \%$ in draught power. Total milk and beef produced in the country is estimated to be 33.2 and 1.2 million tonnes, respectively (12). About 63\% of Pakistani buffaloes fall into the five breeds Nili, Ravi, Nili-Ravi, Kundhi, and Azi-Kheli, while the remaining $37 \%$ are not morphologically or geographically ascribed to any breed. These buffaloes are usually reared in small herds (1-2 or to 10 animals per herd) under rural subsistence and rural market-oriented production systems. Nili-Ravi and Kundhi are the main breeds. Nili-Ravi is a breed from the riverine Punjab, whereas Kundhi inhabit irrigated Sindh. The trade in Nili-Ravi and Kundhi animals from these tracts to other areas of all four Pakistani provinces and Kashmir is common due to their superior milk production over other breeds and nondescript buffaloes (16). This tendency along with inbreeding problems and import of exotic animals for milk production may be damaging to Pakistani buffalo in the future. Therefore, attempts need to be made at national level to keep defined breeds genetically pure and conserved, and to improve their economic potential by strategic breeding. The breeding and conservation of future livestock will largely depend on the evaluation of their genetic diversity. In this context, we have attempted in the present preliminary study to evaluate the genetic variability in all five well-known Pakistani buffalo breeds. Furthermore, it will provide information on the genetic relatedness of the individuals, which can be employed for instance to support the natural populations in the coming years if necessary and infer strategies for the enrichment of the GenBank samples for buffalo in Pakistan. 


\section{Material and Methods}

Sample collection and DNA extraction. A total of 123 animals from five well-known Pakistani buffalo breeds were selected from their respective breeding tracts and government livestock farms (Fig. 1). As herd books covering information regarding parentage were unavailable, animals from different families having no blood relation were sampled after interviewing the local farmers and farm managers. Blood samples $10 \mathrm{~mL}$ in volume were aseptically collected from the jugular vein of 25 animals of Nili breed, 25 of Ravi, 28 of Nili-Ravi, 25 of Kundhi, and 20 of Azi-Kheli. The coagulation of blood samples was blocked with the use of K3 EDTA and DNA was isolated from the peripheral leukocytes using organic extraction (32).

Selection and amplification of microsatellite markers. Eight microsatellite markers on the genome of the Pakistani buffalo (ETH10, INRA005, ILSTS029，ILSTS033，ILSTS049， ILSTS052, ETH225, and CSSM66) which have been recommended by the FAO Measurement of Domestic Animal Diversity (MoDAD) for genetic diversity analysis in cattle were selected to be amplified. The selection of markers was dependent upon their informativeness (polymorphic information content $(\mathrm{PIC})=0.30-0.80)$ and rigorous amplification on the genomes either of Indian cattle or buffalo $(2,15,25)$. Information on bovine chromosomal location of each studied marker, 5' fluorescent label for forward primer and alleles amplified per marker per breed is given in Table 1.

Table 1. Bovine chromosomal location and fluorescence labelling

\begin{tabular}{lllll}
\hline & $\begin{array}{l}\text { Microsatellite } \\
\text { markers }\end{array}$ & $\begin{array}{l}\text { Chromosomal } \\
\text { location }\end{array}$ & $\begin{array}{l}\text { 5' labelling } \\
\text { with } \\
\text { fluorescence }\end{array}$ & $\begin{array}{l}\text { Fragment } \\
\text { length }\end{array}$ \\
\hline 1 & ETH 10 & 5 & PET & 221 \\
2 & INRA 5 & 12 & NED & 118 \\
3 & ILST 029 & 3 & VIC & 159 \\
4 & ILST033 & 12 & FAM & 157 \\
5 & ILST049 & 11 & NED & 165 \\
6 & ILST052 & 21 & PET & 145 \\
7 & ETH225 & 9 & VIC & 147 \\
8 & CSSM66 & 14 & FAM & 196 \\
\hline
\end{tabular}

Multiplexing of the selected markers was achieved in two PCR reactions according to their $5^{\prime}$ fluorescent label and fragment length. The first PCR reaction contained ETH10, INRA005, ILSTS029, and ILSTS033, while the second PCR reaction included ILSTS049, ILSTS052, ETH225, and CSSM66. Amplification in both of the PCR reactions was carried out in a total volume of $25 \mu \mathrm{L}$ consisting of $50 \mathrm{ng}$ of DNA, $10 \mathrm{mM}$ of Tris $\mathrm{HCl}\left(\mathrm{pH} 8.8\right.$ at $\left.25^{\circ} \mathrm{C}\right), 50 \mathrm{mM}$ of $\mathrm{KCl}$, $0.08 \%$ of Nonidet P40, $2 \mathrm{mM}$ of $\mathrm{MgCl}_{2}, 250 \mu \mathrm{M}$ of each dNTP, $0.2 \mu \mathrm{M}$ of each primer, and $0.5 \mathrm{U}$ of Taq polymerase. Touchdown PCR temperature profile was used for amplification, which included initial denaturation at $94^{\circ} \mathrm{C}$ for $5 \mathrm{~min}$ followed by 10 cycles of denaturation at $94^{\circ} \mathrm{C}$ for $30 \mathrm{sec}$, annealing at $64^{\circ} \mathrm{C}-54^{\circ} \mathrm{C}$ (decrease in temperature was set at $1^{\circ} \mathrm{C} /$ cycle) for $30 \mathrm{sec}$ and extension at $72^{\circ} \mathrm{C}$ for $45 \mathrm{sec}$. Following these 10 cycles with variant annealing temperatures, 25 cycles with constant annealing temperature of $54^{\circ} \mathrm{C}$ were performed and the reaction was ended with a final extension step at $72^{\circ} \mathrm{C}$ for $10 \mathrm{~min}$. PCR products mixed with Formamide and DNA size standard were denatured at $95^{\circ} \mathrm{C}$ for $5 \mathrm{~min}$ and loaded into an $\mathrm{ABI}$ 3100 capillary DNA analyser (Applied Biosystems, USA) for separation and detection. GeneScan software version 3.1 (Applied Biosystems) was used for allele size determination in comparison with size standard.

Statistical analysis. Allele frequencies, observed number of alleles, expected number of alleles (17), and observed and expected heterozygosity values (19, $27,29)$ were computed with the use of version 1.31 of the POPGENE software package (36). Expected genotypic frequencies computed using the algorithm by Levene (19) assuming an environment of random mating were used to perform chi-square $\left(\chi^{2}\right)$ and likelihood ratio (G2) tests for Hardy-Weinberg equilibrium at each locus. Chi-square and likelihood ratio tests were also exercised to test the homogeneity in allele distribution at each locus among all the studied breeds. Allele frequencies were used to calculate PIC for each locus as described by Botstein et al. (5). Values for heterozygote deficiency or excess (F-statistics) and gene flow were estimated according to Wright (29) and Yeh (36). The EwensWatterson test for neutrality was performed after Manly (21) as was a linkage disequilibrium (LD) test after Weir (35). Nei's standard and unbiased measures for genetic distance (Ds) were calculated $(26,29)$ and used to construct dendrograms. The divergence times between different pairs of the studied breeds were estimated using the equation $D s=2 \alpha t$ (28), where $D s$ is Nei's standard genetic distance (26), $\alpha$ is the assumed mutation rate, and $t$ is the time of divergence in generations. The mutation rate of $1.4 \times 10^{-4} /$ locus/gamete determined for sheep (9) was considered as $\alpha$ as this value remains to be determined for buffalo.

\section{Results}

Two (ETH10 and ETH225) of the eight studied markers were found to be monomorphic in Pakistani buffaloes. The remaining six loci showed polymorphism in the range of 2 (ILSTS049) to 10 (ILSTS029) in all studied breeds. However, CSSM66 
showed monomorphism in Kundhi and Azi-Kheli (Table 2). In total, 42 alleles were detected across the six polymorphic loci for all the five breeds. Nili showed the maximum number of alleles at 32 while Azi-Kheli displayed the minimum with 24. All the studied breeds varied significantly in allele distribution at each locus except ILSTS049 (P > 0.05). Allele frequency distribution across all loci for each breed is shown in Table 2. The overall allele frequency varied from 0.0041 for alleles B, I, and $\mathrm{J}$ over respective loci ILSTS052, INRA005, and ILSTS029 to 0.80 for allele H over locus ILSTS029. The average PIC value was estimated to be 0.525 across all loci in all five breeds with a range of 0.30 (ILSTS049) to 0.77 (INRA005) (Table 3).

Departures from Hardy-Weinberg equilibrium (HWE) were tested for single as well as multiple populations. Multiple population analysis revealed all loci except ILSTS049 deviated from HWE with a P-value for the $\chi^{2}$ test of less than 0.05 , while only the three loci INRA005, ILSTS033, and CSSM66 were seen deviated from HWE when likelihood ratio (G2) tests $(\mathrm{P}<0.05)$ were performed for HWE at each locus. Single population analyses revealed deviation for a single locus ILSTS033 in Ravi while this was the case for the three loci INRA005, ILSTS029, and ILSTS033 in Nili-Ravi (Table 3). The EwensWatterson test for neutrality showed that the observed $\mathrm{F}$ value for ILSTS029 did not fall within the 95\% confidence interval (L95 and U95) (>U95) in Nili and Nili-Ravi after using 1,000 simulated samples. Linkage disequilibrium was detected for a single breed, Nili-Ravi, between loci ILSTS029 (allele E) and ILSTS052 (allele G) $(\mathrm{r}=0.50$ and $\mathrm{P}<0.01)$.

The total number of observed alleles across all polymorphic loci averaged to $4.00 \pm 2.10$ in Azi-Kheli and to $5.33 \pm 2.34$ in Nili with a mean \pm SD value of $7.00 \pm 3.23$ for all five breeds. The expected number of alleles across all polymorphic loci averaged to $2.11 \pm 0.92$ in Azi-Kheli and to $2.75 \pm 1.93$ in Nili-Ravi with a mean $\pm \mathrm{SD}$ value of $2.52 \pm 1.27$ for all five breeds (Table 3). The maximum number of alleles was observed at loci INRA005 in Nili-Ravi and Kundhi and ILSTS052 in Nili. The mean values for observed heterozygosity (Ho) ranged from $0.41 \pm 0.25$ in NiliRavi and Kundhi to $0.47 \pm 0.22$ in Nili. These counterpoint the mean values for expected heterozygosity (He) varying from $0.44 \pm 0.28$ in Azi-Kheli to $0.55 \pm 0.13$ in Ravi. The overall mean Ho and He values calculated for all breeds were $0.43 \pm 0.17$ and $0.53 \pm 0.18$, respectively.

The mean estimates of Fis (f), Fit (F), Fst ( $(\theta)$, and gene flow $(\mathrm{Nm})$ across all loci in all breeds were calculated as $0.13,0.19,0.07$, and 3.31 , respectively (Table 3). Nei's genetic distance estimates (Ds) ranged from 0.0374 between Nili and Ravi to 0.1747 between Nili and Azi-Kheli. Based on Ds values, Nili, Ravi, and Nili-Ravi clustered together as was expected whereas Kundhi and Azi-Kheli made another cluster. Assuming a generation time of 6.5 years for Pakistani buffaloes (16), Nili and Azi-Kheli diverged 4,056 years ago and Ravi and Azi-Kheli 4,016 years ago (Fig. 2).

Table 2. Number of alleles detected per locus per breed

\begin{tabular}{|c|c|c|c|c|c|c|}
\hline Locus/population & Breeds & Nili & Ravi & $\begin{array}{l}\text { Nili- } \\
\text { Ravi }\end{array}$ & Kundhi & Azi-Kheli \\
\hline $\begin{array}{l}\text { ETH10 }\{\text { PET }\} \\
\text { (5) }\end{array}$ & A (198) & $\mathrm{A}$ & $\mathrm{A}$ & $\mathrm{A}$ & A & A \\
\hline $\begin{array}{l}\text { INRA005 } \\
\{\text { NED }\}(12)\end{array}$ & $\begin{array}{l}\text { A (110), B (112), C (116), D } \\
(122), \text { E (124), F (126), G } \\
(128), H(130), \text { I (132) }\end{array}$ & $\begin{array}{l}\mathrm{B}, \mathrm{C}, \mathrm{D}, \mathrm{E}, \\
\mathrm{G}, \mathrm{H}, \mathrm{I}\end{array}$ & $\mathrm{B}, \mathrm{C}, \mathrm{E}, \mathrm{F}, \mathrm{G}$ & $\begin{array}{l}\text { A, B, C, } \\
\text { D, E, F, } \\
\text { G, H }\end{array}$ & $\begin{array}{l}\text { A, B, C, D, E, F, G, } \\
\mathrm{H}\end{array}$ & $\mathrm{B}, \mathrm{E}, \mathrm{F}, \mathrm{H}$ \\
\hline $\begin{array}{l}\text { ILSTS029 }\{\mathrm{VIC}\} \\
\text { (3) }\end{array}$ & $\begin{array}{l}\text { A (138), B (144), C (146), D } \\
(150), \text { E (152), F (158), G } \\
(170), H(172), J(168)\end{array}$ & $\begin{array}{l}\text { A, B, C, E, } \\
\text { H, I }\end{array}$ & $\begin{array}{l}\text { A, B, C, D, } \\
\text { E, H }\end{array}$ & $\begin{array}{l}\text { A, C, D, } \\
\text { E, F, H }\end{array}$ & $\mathrm{D}, \mathrm{F}, \mathrm{G}, \mathrm{H}, \mathrm{I}$ & $\mathrm{E}, \mathrm{F}, \mathrm{G}, \mathrm{H}, \mathrm{J}$ \\
\hline $\begin{array}{l}\text { ILSTS033 } \\
\{\text { FAM }\}(12)\end{array}$ & $\begin{array}{l}\text { A (138), B (142), C (144), D } \\
(146), \text { E (152), F (154), G } \\
(170), \text { H (172), }\end{array}$ & $\mathrm{A}, \mathrm{B}, \mathrm{C}, \mathrm{E}$ & $\begin{array}{l}\text { A, B, C, D, } \\
\text { E, G, H }\end{array}$ & $\begin{array}{l}\mathrm{A}, \mathrm{B}, \mathrm{C} \\
\mathrm{D}, \mathrm{G}, \mathrm{H}\end{array}$ & $\mathrm{A}, \mathrm{B}, \mathrm{C}, \mathrm{E}, \mathrm{F}$ & $\mathrm{A}, \mathrm{B}, \mathrm{C}, \mathrm{D}, \mathrm{E}, \mathrm{F}$ \\
\hline $\begin{array}{l}\text { ILSTS049 } \\
\{\text { NED }\}(11)\end{array}$ & A (134), B (136) & A, B & A, B & A, B & A, B & A, B \\
\hline $\begin{array}{l}\text { ILSTS052 }\{\text { PET }\} \\
\text { (21) }\end{array}$ & $\begin{array}{l}\text { A (148), B (152), C (154), D } \\
(156), \text { E (158), F (160), G } \\
(162), H(172), \text { I (178) }\end{array}$ & $\begin{array}{l}\text { A, B, C, E, } \\
\text { F, G, H, I }\end{array}$ & $\begin{array}{l}\text { A, C, E, G, } \\
\text { H, I }\end{array}$ & $\begin{array}{l}\mathrm{A}, \mathrm{D}, \mathrm{E} \\
\mathrm{G}, \mathrm{H}\end{array}$ & $\mathrm{A}, \mathrm{D}, \mathrm{E}, \mathrm{F}, \mathrm{G}, \mathrm{I}$ & $\mathrm{A}, \mathrm{C}, \mathrm{D}, \mathrm{E}, \mathrm{G}, \mathrm{I}$ \\
\hline $\begin{array}{l}\text { ETH225 }\{\mathrm{VIC}\} \\
\text { (9) }\end{array}$ & A (122) & A & A & A & A & A \\
\hline $\begin{array}{l}\text { CSSM66 }\{\text { FAM }\} \\
(14)\end{array}$ & $\begin{array}{l}\text { A (174), B (178), C (180), D } \\
(184)\end{array}$ & $\mathrm{A}, \mathrm{B}, \mathrm{C}, \mathrm{D}$ & $\mathrm{A}, \mathrm{B}, \mathrm{C}, \mathrm{D}$ & $\begin{array}{l}\text { A, B, C, } \\
\text { D }\end{array}$ & $\mathrm{D}$ & $\mathrm{D}$ \\
\hline Total alleles & 4,434 & 32 & 32 & 33 & 29 & 26 \\
\hline
\end{tabular}

\{\}$-5^{\prime}$ fluorescent label for forward primer; () - bovine chromosomal location of corresponding marker 
Table 3. Within- and between-population genetic diversity estimates for the studied breeds

\begin{tabular}{|c|c|c|c|c|c|c|c|}
\hline $\begin{array}{l}\text { Population / } \\
\text { Locus }\end{array}$ & INRA005 & ILSTS029 & ILSTS033 & ILSTS049 & ILSTS052 & CSSM66 & $\begin{array}{l}\text { All loci } \\
(\text { mean } \pm \text { SD) }\end{array}$ \\
\hline \multicolumn{8}{|l|}{ Nili } \\
\hline na (ne) & $7(2.75)$ & $7(1.41)$ & $4(2.51)$ & $2(1.63)$ & $8(2.12)$ & $4(3.21)$ & $\begin{array}{l}5.33 \pm 2.34 \\
(2.27 \pm 0.69)\end{array}$ \\
\hline Ho $(\mathrm{He})$ & $0.68(0.65)$ & $0.32(0.3)$ & $0.24(0.61)$ & $0.28(0.39)$ & $0.56(0.54)$ & $0.76(0.7)$ & $\begin{array}{l}0.47 \pm 0.22 \\
(0.53 \pm 0.16)\end{array}$ \\
\hline Nei's He & 0.64 & 0.29 & 0.6 & 0.39 & 0.53 & 0.69 & $0.52 \pm 0.16$ \\
\hline Fis & -0.07 & -0.11 & 0.6 & 0.27 & -0.06 & -0.1 & \\
\hline \multicolumn{8}{|l|}{ Ravi } \\
\hline na (ne) & $5(3.0)$ & $6(1.74)$ & $7(2.76)$ & $2(1.52)$ & $6(2.43)$ & $4(2.19)$ & $\begin{array}{l}5.0 \pm 1.79 \\
(2.27 \pm 0.57)\end{array}$ \\
\hline Ho $(\mathrm{He})$ & $0.68(0.68)$ & $0.32(0.43)$ & $0.28(0.65)$ & $0.36(0.35)$ & $0.52(0.6)$ & $0.40(0.55)$ & $\begin{array}{l}0.43 \pm 0.15 \\
(0.55 \pm 0.13)\end{array}$ \\
\hline Nei's He & 0.67 & 0.42 & 0.64 & 0.34 & 0.59 & 0.54 & $0.53 \pm 0.13$ \\
\hline Fis & -0.02 & 0.25 & 0.56 & -0.05 & 0.12 & 0.27 & -0.02 \\
\hline \multicolumn{8}{|l|}{ Nili-Ravi } \\
\hline na (ne) & $8(6.53)$ & $6(1.41)$ & $6(2.93)$ & $2(1.81)$ & $5(2.10)$ & $4(1.71)$ & $\begin{array}{l}5.17 \pm 2.04 \\
(2.75 \pm 1.93)\end{array}$ \\
\hline Ho (He) & $0.89(0.86)$ & $0.18(0.29)$ & $0.25(0.67)$ & $0.39(0.46)$ & $0.36(0.53)$ & $0.36(0.42)$ & $\begin{array}{l}0.41 \pm 0.25 \\
(0.54 \pm 0.2)\end{array}$ \\
\hline Nei's He & 0.85 & 0.29 & 0.66 & 0.45 & 0.52 & 0.41 & $0.53 \pm 0.20$ \\
\hline Fis & -0.05 & 0.38 & 0.62 & 0.12 & 0.32 & 0.14 & -0.05 \\
\hline \multicolumn{8}{|l|}{ Kundhi } \\
\hline na (ne) & $8(3.58)$ & $5(1.87)$ & $5(3.03)$ & $2(1.42)$ & $6(2.02)$ & $1(1.0)$ & $\begin{array}{l}.50 \pm 2.59 \\
(2.15 \pm 0.98)\end{array}$ \\
\hline Ho $(\mathrm{He})$ & $0.76(0.73)$ & $0.40(0.48)$ & $0.56(0.68)$ & $0.36(0.30)$ & $0.4(0.51)$ & $0.0(0.0)$ & $\begin{array}{l}0.41 \pm 0.25 \\
(0.45 \pm 0.27)\end{array}$ \\
\hline Nei's He & 0.72 & 0.47 & 0.67 & 0.29 & 0.5 & 0.0 & $0.44 \pm 0.27$ \\
\hline Fis & -0.05 & 0.14 & 0.16 & -0.22 & 0.21 & 0.0 & -0.05 \\
\hline \multicolumn{8}{|l|}{ Azi-Kheli } \\
\hline na (ne) & $4(2.87)$ & $5(1.37)$ & $6(3.24)$ & $2(1.54)$ & $6(2.65)$ & $1(1.0)$ & $\begin{array}{l}4.00 \pm 2.1 \\
(2.11 \pm 0.92)\end{array}$ \\
\hline Ho (He) & $0.6(0.67)$ & $0.25(0.28)$ & $0.5(0.71)$ & $0.45(0.36)$ & $0.75(0.64)$ & $0.0(0.0)$ & $\begin{array}{l}0.43 \pm 0.27 \\
(0.44 \pm 0.28)\end{array}$ \\
\hline Nei's He & 0.65 & 0.27 & 0.69 & 0.35 & 0.62 & 0.0 & $0.43 \pm 0.27$ \\
\hline Fis & 0.08 & 0.08 & 0.28 & -0.29 & -0.21 & 0.0 & 0.08 \\
\hline \multicolumn{8}{|l|}{ All breeds } \\
\hline na (ne) & $9(4.76)$ & $10(1.57)$ & $8(3.25)$ & $2(1.6)$ & $9(2.28)$ & $4(1.67)$ & $\begin{array}{l}7.0 \pm 3.23 \\
(2.52 \pm 1.27)\end{array}$ \\
\hline Ho $(\mathrm{He})$ & $0.73(0.79)$ & $0.29(0.37)$ & $0.36(0.7)$ & $0.37(0.38)$ & $0.5(0.56)$ & $0.32(0.4)$ & $\begin{array}{l}0.43 \pm 0.17 \\
(0.53 \pm 0.18)\end{array}$ \\
\hline Nei's He & 0.79 & 0.36 & 0.69 & 0.37 & 0.56 & 0.4 & $0.53 \pm 0.18$ \\
\hline Fis & 0.07 & 0.2 & 0.48 & 0.02 & 0.1 & 0.21 & 0.07 \\
\hline PIC & 0.77 & 0.35 & 0.64 & 0.3 & 0.54 & 0.55 & 0.525 (mean) \\
\hline \multicolumn{8}{|c|}{ Nei's (1987) F-statistics and gene flow } \\
\hline Fis & -0.03 & 0.16 & 0.44 & -0.01 & 0.06 & 0.08 & 0.13 (mean) \\
\hline Fit & 0.09 & 0.19 & 0.48 & 0.003 & 0.08 & 0.22 & 0.19 \\
\hline Fst & 0.11 & 0.04 & 0.07 & 0.016 & 0.02 & 0.15 & 0.07 \\
\hline $\mathrm{Nm}$ & 2.1 & 5.93 & 3.56 & 15.84 & 12.78 & 1.38 & 3.31 \\
\hline
\end{tabular}

na - observed number of alleles, ne - expected number of alleles, Ho - observed heterozygosity, $\mathrm{He}$ - expected heterozygosity, Nei's He Nei's expected heterozygosity, PIC - polymorphic information content, Fis - estimate of within-population inbreeding, Fit - estimate of global inbreeding, Fst - estimate of population differentiation, $\mathrm{Nm}$ - gene flow estimated from Fst

Table 4. P-values in Chi-square/likelihood ratio test for HWE

\begin{tabular}{lllllll}
\hline Population/Locus & INRA005 & ILSTS029 & ILSTS033 & ILSTS049 & ILSTS052 & CSSM66 \\
\hline Nili & - & - & - & $0.000 / 0.000$ & - & $0.004 / 0.990$ \\
\hline Ravi & - & - & - & $0.000 / 0.003$ & - & - \\
\hline Nili-Ravi & $0.015 / 0.191$ & $0.000 / 0.524$ & $0.000 / 0.000$ & - & - & - \\
\hline Kundhi & - & $0.000 / 0.074$ & - & - & - & $0.000 / 0.084$ \\
\hline Azi-Kheli & - & $0.040 / 0.734$ & $0.005 / 0.142$ & - & - & - \\
\hline All breeds & $0.000 / 0.000$ & $0.000 / 0.712$ & $0.000 / 0.000$ & - & $0.000 / 0.171$ & $0.000 / 0.013$ \\
\hline
\end{tabular}




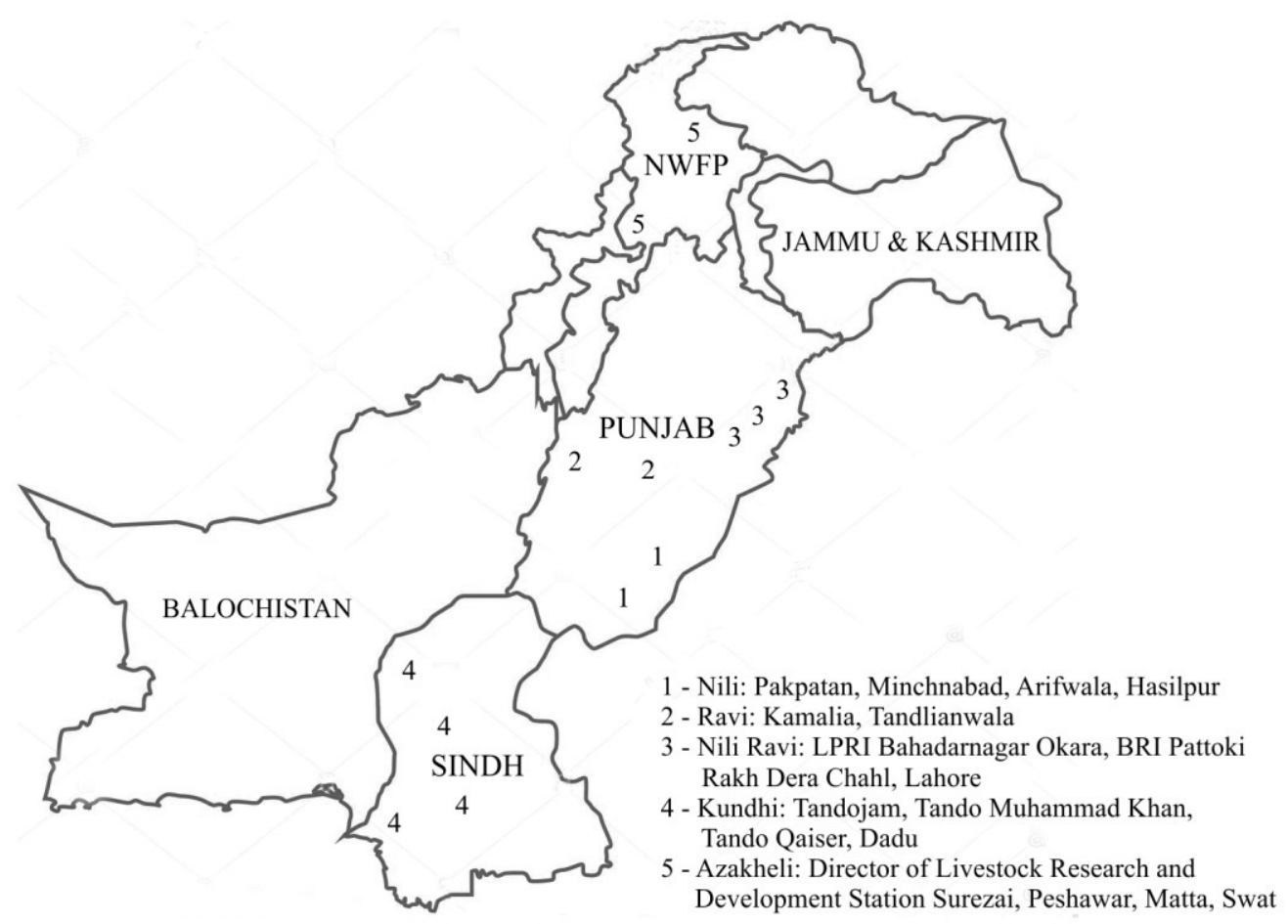

Fig. 1. Map of Pakistan showing sampling locations of the studied buffalo breeds. Numbers in the legend correspond to the numbers typed on the map and present information about breeding tracts of the studied breeds

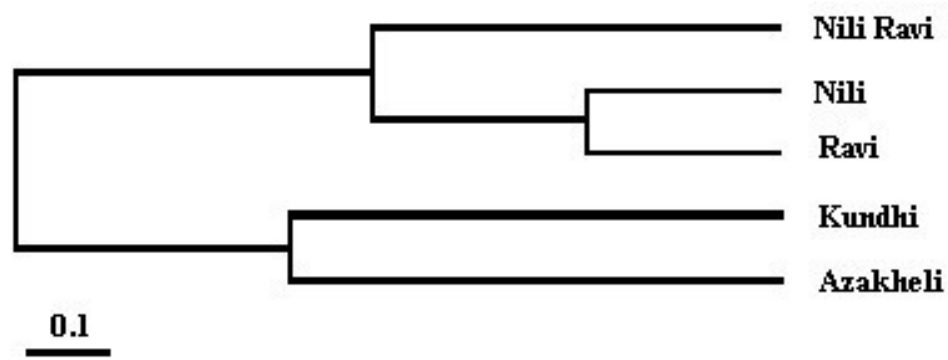

Fig. 2. UPGMA-method-based dendrogram splitting the studied breeds into two distinct clusters. The dendrogram was constructed using Nei's (26) original measures of genetic distance (Ds) between different pairs of the studied breeds. Ds values are tabulated below the dendrogram along with divergence times calculated for all possible breed-pairs

\section{Discussion}

The present study provides the first source of information on genetic variation in Pakistani buffaloes assessed by using eight microsatellite markers located at seven different bovine chromosomes. Moderate levels of both allelic and genetic diversity were observed for the studied breeds. Although some specific alleles were present in all five breeds, they cannot be considered as breed-specific markers due to their lower frequency, attributable to the small sample size. Among the studied breeds, Kundhi and Azi-Kheli are morphologically so distinct from Nili, Ravi, and Nili-Ravi that they can be identified by the layman as different breeds. However, Nili, Ravi, and Nili-Ravi can generally be distinguished only by trained persons on the basis of minute variation in their body size. These three breeds have been declared a single breed Nili-Ravi (a crossbred of Nili and Ravi) since the 1960 s, although farmers living in the breeding tracts of Nili and Ravi still claim that their animals are pure bred (16). In the present study, an almost equal number of total alleles per breed were observed in Nili, Ravi, and Nili-Ravi (Table 2). Moreover, these breeds varied in allele frequency distribution significantly $(\mathrm{P}<0.05)$ at only two loci (INRA005 and ILSTS052) (Table 2), and clustered together as a separate group in the dendrogram (Fig. 2). Regardless of sample size and 
number of markers used in the study, these results favour the consideration of Nili and Ravi as a single Nili-Ravi breed. The differentiation of Nili from Ravi and Nili-Ravi based on allele frequency distribution can, however, be commercially beneficial because most of the Punjabi farmers show preference for rearing Nili over other breeds. A marker based on a homozygosity pattern in the PRKAG3 gene has previously been described for this purpose $(1,3)$.

The markers with PIC values less than 0.25 are considered less informative while those with values greater than 0.50 are very informative for the study of genetic variation (5). The PIC values for the markers used in this study averaged to 0.525 within a range of 0.30 (ILSTS049) to 0.77 (INRA005) (Table 4), indicating the suitability of these markers for genetic diversity analysis in Pakistani buffaloes. ILSTS029 is comparatively more polymorphic in Pakistani buffaloes than in Indian Marathwada $(9,15)$, Bhadawari, and Tarai buffaloes (2), although average PIC values calculated for all studied markers in these Pakistani and Indian breeds are very similar $(0.54<0.525<0.565)$.

Measures of $\mathrm{Ho}$ and $\mathrm{He}$ estimated for Pakistani buffalo are comparable with those estimated for Chinese buffalo (37) and Indian Banni and Chilika buffalo breeds $(23,31)$. However, these measures are remarkably lower for Pakistani buffalo than for other Asian $(2,4,15,18)$ and Mediterranean buffaloes (10, 24). The lower heterozygosity calculated for the studied breeds can possibly be attributed to the small sample size used in the present study. Small sample size, presence of null alleles and the Wahlund effect are considered major causes of heterozygote deficiency and ultimately of deviation from HWE. In this study, within-population heterozygote deficiency or inbreeding (Fis) and global heterozygote deficiency (Fit) were estimated at a rate of $13 \%$ and $17 \%$, respectively. Possibly due to this heterozygote deficiency, 15 out of 36 population-locus combinations were found deviated from HWE (Table 3).

To analyse the patterns of gene flow (Nm) among breeds and their impact on breed differentiation (Fst), the five breeds were divided into two groups: the Nili+Ravi+Nili-Ravi group and the Kundhi+Azi-Kheli group. By doing this, the value of Nm doubled (6.47) in comparison with the 3.31 value that was obtained when all breeds were analysed individually. The $\mathrm{Nm}$ value further increased (7.64) by removing the Kundhi and Azi-Kheli breed data from the analysis. This difference in $\mathrm{Nm}$ estimates points out that trade in Nili-Ravi is preferred over trade in other breeds in the whole of Pakistan as also described by Khan et al. (16). Moreover, female animals contribute to this trade much more as indicated by the difference in Fst measures. The Fst value decreased to half both by grouping the breeds into two (0.0372) and removing the Kundhi+Azi-Kheli group from analysis (0.317). Fst was estimated to be 0.07 when all breeds were analysed individually. Bruford et al. (6) has described how breed differentiation (Fst) might be the result of intensive selection operating mainly through paternal lineages rather than through maternal lineages. Considering this reason, the use of a small number of breeding bulls have possibly imposed some selective pressure on animals of the Nili+Ravi+Nili-Ravi group. This proposition is supported by three points: 1) all loci except ILSTS049 and CSSM66 showed LD in this group while LD was not seen for any locus in Kundhi+Azi-Kheli group, 2) the only non-neutral locus (ILSTS029) was observed for this group, and 3) there was much more difference in Ho and He values in both groups. Ho and He values were computed to be 0.43 and 0.55 , and 0.42 and 0.46 for Nili+Ravi+Nili-Ravi and Kundhi+Azi-Kheli groups, respectively.

Altogether, the analyses presented in this study provide preliminary data on genetic diversity and population structure of Pakistani buffalo, and might be helpful for similar studies in other livestock breeds of Pakistan.

Conflict of Interests Statement: The authors declare that there is no conflict of interests regarding the publication of this article.

Financial Disclosure Statement: This work was supported by the Virtual University of Pakistan (Grant no. 2016871856).

Animal Rights Statement: The authors declare that all experiments on animals were conducted in accordance with the provisions of EU animal management practices under controllable situations. This study was carried out according to the Guidelines for the Care and Use of Animals of Virtual University of Pakistan and animal experiments were approved by Care and Use of Animals Center, Virtual University of Pakistan.

Acknowledgement: The authors are thankful to the Livestock and Dairy Development Departments of the Punjab, Sindh and Khyber Pakhtunkhwa for helping in the sample collection.

\section{References}

1. Abbas G.: Phylogenetic relationship among buffalo breeds of Pakistan using RAPD analysis. MSc Thesis. Depart. Anim. Breed. Genet., Univ. Agri. Faisalabad, Pakistan 2007.

2. Arora R., Lakhchaura P.R.B., Tantia M.S., Vijh R.K.: Genetic diversity analysis of two buffalo populations of northern India using microsatellite markers. J Anim Breed Genet 2004, 121, 111-118.

3. Babar M.E., Imran M., Nawaz M., Benkel B.F., Farid H., Jabeen R., Abdullah M., Javed M., Javed M.: Genetic identification of three Pakistani buffalo breeds through a homozygosity pattern in the PRKAG3 gene. Pak J Zool 2008, 40, 409-415.

4. Barker J.S.F., Moore S.S., Hetzel D.J.S., Evans D., Tan S.G., Byrne K.: Genetic diversity of Asian water buffalo (Bubalus bubalis): microsatellite variation and a comparison with proteincoding loci. Anim Genet 1997, 28, 103-115. 
5. Botstein D., White R.L., Skolnick M., Davis R.W.: Construction of a genetic linkage map in man using restriction fragment length polymorphisms. Am J Hum Genet 1980, 32, 314-331.

6. Bruford M.W., Bradley D.G., Luikart G.: DNA markers reveal the complexity of livestock domestication. Nature Rev Genet 2003, 4, 900-910.

7. Cañón J., García D., García-Atance M.A., Obexer-Ruff G., Lenstra J.A., Ajmone-Marsan P., Dunner S.: Geographical partitioning of goat diversity in Europe and the Middle East. Anim Genet 2006, 37 327-334.

8. Consortium E.C.G.D.: Marker-assisted conservation of European cattle breeds: an evaluation. Anim Genet 2006, 37, 475-481.

9. Crawford A.M., Cuthbertson R.P.: Mutations in sheep microsatellites. Genome Res 1996, 6, 876-879.

10. Elbeltagy A.R., Galal S., Abdelsalam A.Z., El-Keraby F.E., Blasi M. Mohamed M.M.: Biodiversity in Mediterranean buffalo using two microsatellite multiplexes. Livest Sci 2008, 114, 341-346.

11. FAO: Animal production and health guidelines. Molecular genetic characterization of Animal Genetic Resources. Commission on Genetic Resources for Food and Agriculture Food and Agriculture Organization of the United Nations. Rome, Italy, 2011.

12. GOP: GEconomic Survey, 2006-2007. Economic Affairs Division, Government of Pakistan, Isalamabad 2007.

13. GOP: Economic Survey, 2007-2008. Economic Affairs Division, Government of Pakistan, Isalamabad 2008.

14. Hillel J., Groenen M.A.M., Tixier-Boichard M., Korol A.B., David L., Kirzhner V.M., Burke T., Barre-Dirie A., Crooijmans R.P.M.A., Elo K., Feldman M.W., Freidlin P.J., Mäki-Tanila A, Oortwijn M., Thomson P., Vignal A., Wimmers K., Weigend S.: Biodiversity of 52 chicken populations assessed by microsatellite typing of DNA pools. Genet Sel Evol 2003, 35, 533-357.

15. Kathiravan P., Mishra B.P., Kataria R.S., Sadana D.K.: Evaluation of genetic architecture and mutation drift equilibrium of Marathwada buffalo population in Central India. Livest Sci 2008, 5, 13-17.

16. Khan M.S., Ahmad N., Khan M.A.: Genetic resources and diversity in dairy buffaloes of Pakistan. Pak Vet J 2007, 27, 201-207.

17. Kimura M., Crow J.F.: The number of alleles that can be maintained in a finite population. Genetics 1964, 49, 725-738.

18. Kumar S., Gupta J., Kumar N., Dikshit K., Navani N., Jain P., Nagarajan M.: Genetic variation and relationships among eight Indian riverine buffalo breeds. Mol Ecol 2006, 15, 593-600.

19. Levene H.: On a matching problem in genetics. Ann Math Stat 1949, 20, 91-94.

20. Lindgren G., Backström N., Swinburne J., Hellborg L., Einarsson A., Sandberg K., Cothran G., Vilà C., Binns M., Ellegren H.: Limited number of patrilines in horse domestication. Nature Genet 2004, 36, 335-336.

21. Manly B.F.J.: The statistics of natural selection on animal populations. Chapman and Hall, London 1985.

22. Michelizzi V.N., Dodson M.V., Pan Z., Amaral M.E.J., Michal J.J., McLean D.J., Womack J.E., Jiang Z.: Water buffalo genome science comes of age. Int Biol Sci 2010, 6, 333-349.
23. Mishra B.P., Kataria R.S., Bulandi S.S., Prakash B., Kathiravan P., Mukesh M., Sadana D.K.: Riverine status and genetic structure of Chilika buffalo of eastern India as inferred from cytogenetic and molecular marker-based analysis. J Anim Breed Genet 2009, 126, 69-79.

24. Moioli B., Georgoudis A., Napolitano F., Catillo G., Giubilei E., Lgda C., Hassanane M.: Genetic diversity between Italian, Greek, and Egyptian buffalo populations. Live Prod Sci 2001, 70, 203-211.

25. Mukesh M., Sodhi M., Bhatia S., Mishra B.P.: Genetic diversity of Indian native cattle breeds as analyzed with 20 microsatellite loci. J Anim Breed Genet 2004, 121, 416-424.

26. Nei M.: Genetic distance between populations. Amer Nat 1972, 106, 283-292.

27. Nei M.: Analysis of gene diversity in subdivided populations. Proc Natl Acad Sci U.S.A 1973, 70, 3321-3323.

28. Nei M.: Mathematical models of speciation and genetic distance. In: Population Genetics and Ecology. Edited by Karlin S., Nevo E., Academic Press, New York, 1976, pp. 723-766.

29. Nei M.: Estimation of average heterozygosity and genetic distance from a small number of individuals. Genetics 1978, 89, 583-590.

30. Peter C., Bruford M., Perez T., Dalamitra S., Hewitt G., Erhardt G.: Genetic diversity and subdivision of 57 European and MiddleEastern sheep breeds. Anim Genet 2007, 38, 37-44.

31. Sajid I.A.: Molecular genetic variation among Nili, Ravi and Nili-Ravi buffalo breeds. MSc Thesis. Dept. Anim. Breed. Genet., Univ. Agri. Faisalabad, Pakistan, 2005.

32. Sambrook J., Russell D.W.: Molecular cloning: a laboratory manual. Cold Spring Harbor Laboratory Press, Cold Spring Harbor, New York 2001.

33. SanCristobal M., Chevalet C., Haley C.S., Joosten R., Rattink A.P., Harlizius B., Groen M.A.M, Amigues Y., Boscher M.Y., Russell G., Law A., Davoli R., Russo V., Désautés A., Fimland E., Bagga M., Delgado J.V., Vega-Pla J.L., Martinez A.M., Ramos M., Glodek P., Meyer J.N., Gandini G.C., Matassino D., Plastow G.S., Siggens K.W., Laval G., Archibald A.L., Milan D., Hammond K., Cardellino R. Genetic diversity within and between European pig breeds using microsatellite markers. Anim Genet 2006, 37, 189-198.

34. Toro M.A., Fernández J., Caballero J.: Molecular characterization of breeds and its use in conservation. Livest Sci 2009, 120, 174-195.

35. Weir B.S.: Inferences about linkage disequilibrium. Biometrics 1979, 35, 235-254

36. Yeh F., Boyle C., Rongcai T., Ye Z.Y., Xian J.M.: A Microsoft window based free ware for population genetic analysis. University of Alberta, Edmonton (available at: http://www.ualberta.ca/ fyeh/). 1999.

37. Zhang Y., Sun D., Yu Y., Zhang Y.: Genetic diversity and differentiation of Chinese domestic buffalo based on 30 microsatellite markers. Anim Genet 2007, 38, 569-575. 